\title{
Status of Underutilised Crops in South Africa: Opportunities for Developing Research Capacity
}

\author{
Tafadzwanashe Mabhaudhi * (1), Vimbayi G. P. Chimonyo (i) and Albert T. Modi \\ Crop Science, School of Agricultural, Earth and Environmental Sciences, University of KwaZulu-Natal, \\ Private Bag X01, Scottsville, Pietermaritzburg 3209, South Africa; vimbayic@gmail.com (V.G.P.C.); \\ modiat@ukzn.ac.za (A.T.M.) \\ * Correspondence: tmabhaudhi@gmail.com; Tel.: +27-33-260-5442; Fax: +27-33-260-6094
}

Received: 28 July 2017; Accepted: 31 August 2017; Published: 6 September 2017

\begin{abstract}
Underutilised crops represent an important component of agro-biodiversity with potential to contribute to climate change adaptation, food security and sovereignty in poor rural areas. However, despite emerging research interest, they continue to occupy the peripheries of mainstream agriculture. There is a need to consolidate the gains made and propose a coherent strategy for translating underutilised crops into mainstream agriculture. The status of underutilised crops in South Africa (past, present and on-going research) was reviewed with a view to identifying existing gaps, opportunities and challenges for developing future research capacity. The review confirmed that several underutilised crops are drought tolerant, adapted to low levels of water use and thus suitable for cultivation in most marginal production areas typical of semi-arid and arid cropping systems. In addition, several are nutrient dense and could be used to improve dietary diversity among poor rural people. These characteristics make them ideal for inclusion in climate change adaptation and promotion of food sovereignty. There is need for a paradigm shift away from practices that have promoted a few major crops to an agro-ecology based land use classification system that recognises diversity and strengthens food networks. There is a need to identify those underutilised crops that show the greatest potential for success and can be fitted into semi-arid and arid cropping systems and prioritise them for future research, development and innovation.
\end{abstract}

Keywords: climate change; food and nutrition security; food sovereignty; sustainable; water scarcity

\section{Introduction}

Increasingly, low and variable rainfall patterns in South Africa threaten the viability and sustainability of rural food systems, hence threatening food and nutrition security, as well as food sovereignty, in poor rural households. The potential of underutilised crops to contribute under such conditions has been highlighted in several publications [1-4]. However, despite reports of their potential and emerging interest on underutilised crops, research on them remains scant. Some of these underutilised crops would be ideal for promotion during periods of drought since research has shown that they require less water [1]. Most underutilised crops possess attributes that make them ideal for production under low input agricultural systems and in marginal production areas, which typify South Africa's rural landscape. Given the current climate change for South Africa underutilised crops become an important resource for climate change adaptation. However, a paucity of information describing their agronomy, water use and lack of production guidelines have previously been cited as bottlenecks to their promotion.

There have been efforts to quantify the positive attributes of underutilised crops for South Africa; the Water Research Commission of South Africa has invested in their research and development. These efforts have included screening for drought tolerance in several underutilised 
indigenous crops [5], describing the agronomy and determining drought tolerance and water use of selected underutilised indigenous crops [1], and determining nutritional water productivity of underutilised crops [6,7]. Specific crop groups such as underutilised cereals and legume food crops, have also received attention [6,8]. These efforts, coupled with others by the national Department of Science and Technology (DST) and through other external partnerships, have led to an increase in the amount of information available on underutilised indigenous crops. While the current efforts are laudable, these have mainly been guided by the realisation of the potential of underutilised crops and addressing existing knowledge gaps.

While the value of underutilised crops remains sectorial, that is, more important for marginal communities, or a healthy food choice for more health-conscious members of the elite society, information about them remains scanty. Past and present research has focused on generating information on the range of underutilised crops without focus on specific underutilised crops and how they can help tackle current world problems. In addition, the current research has mainly been at the start up point of the value chain with limited focus on the supporting activities of the value chain. This has inadvertently created an incomplete body of literature for underutilised crops and no models for how to transform them from being underutilised to being utilised. Furthermore, there is need for a paradigm change away from the current streamlined agricultural system that is dominated by a few crops to a more diverse system that embraces agro-biodiversity. There is, therefore, a need to consolidate gains by the underutilised crops research community and articulate a way forward for underutilised crops in South Africa.

There is need to articulate a strategy for developing underutilised crops in South Africa with priority given to drought tolerant and nutrient dense crops that can climate change adaptation and food security in rural areas. The strategy should advocate for a paradigm shift in the way agricultural interventions are currently prioritized, developed, funded and implemented. The current system is biased towards major crops and commercial agriculture often to the detriment of smallholder agriculture and small family farmers. An initial step to developing a good strategy involves a systematic diagnosis of the challenges, obstacles and opportunities and developing recommendations for dealing with challenges. Therefore, the objective of this review was to conduct an appraisal of the current status of underutilised crops in terms of research, their role in cropping systems and current crop choices and to identify their potential contribution to national development agenda, in particular, climate change adaptation, food and nutrition security, food sovereignty, as well as employment and wealth creation in poor rural communities. A key focus of the review was aligned to the role that underutilised crops have to play as drought tolerant and nutrient dense crops, especially during drought periods.

\section{Methods}

This paper is a follow-up to an initial study that focused on identifying opportunities for promoting underutilised crops in southern Africa [4]. The current paper provides more specific analyses on South Africa. A mixed method review approach, which included combining quantitative and qualitative research or outcomes with process studies, was used to compile the review. Emphasis was placed on use of literature from South Africa, with limited comparisons to international literature; this allowed for an assessment of local knowledge relative to international knowledge on neglected and underutilised crop species (NUS). Articles were identified through searches on Google Scholar databases for the period from 1960 to August 2016. Other search engines, such as Scopus, ScienceDirect and SpringerLink, were also used. The primary search terms used were "traditional", "indigenous", "neglected", "orphan", "new", "future" or "neglected and underutilised crop species". The search did not discriminate by searching within keywords, titles and abstracts but searched for key terms throughout the articles. As such, the search was largely web-based and designed to cover both grey and academic literature. The main advantage of this was that it extended the search beyond articles that would normally be unavailable for the audience outside research. The number of hits was $\sim 5000$ and these were screened for relevance to the objectives of the review; 
$\sim 80$ were then cited in the text. For identifying opportunities and challenges, approaches used were mainly a critical literature review (i.e., qualitative) using the research value chain.

\section{Aligning Definitions}

According to Blum [9], "correct definitions are not just a matter of formality but rather an essential road map for research". Consensus definitions determine success or failure of research and "lack of consensus of definitions and their proper use in research can undermine attempts to repeat the specific research and its results" [9]. An array of definitions has been used, each with different meaning and context, hence causing an incoherent body of literature on these crops. This study identified the different names that have been used in the literature for the past 50 years (1960-2015). These included traditional, indigenous, neglected, orphan, and new/future crop species (Figure 1).

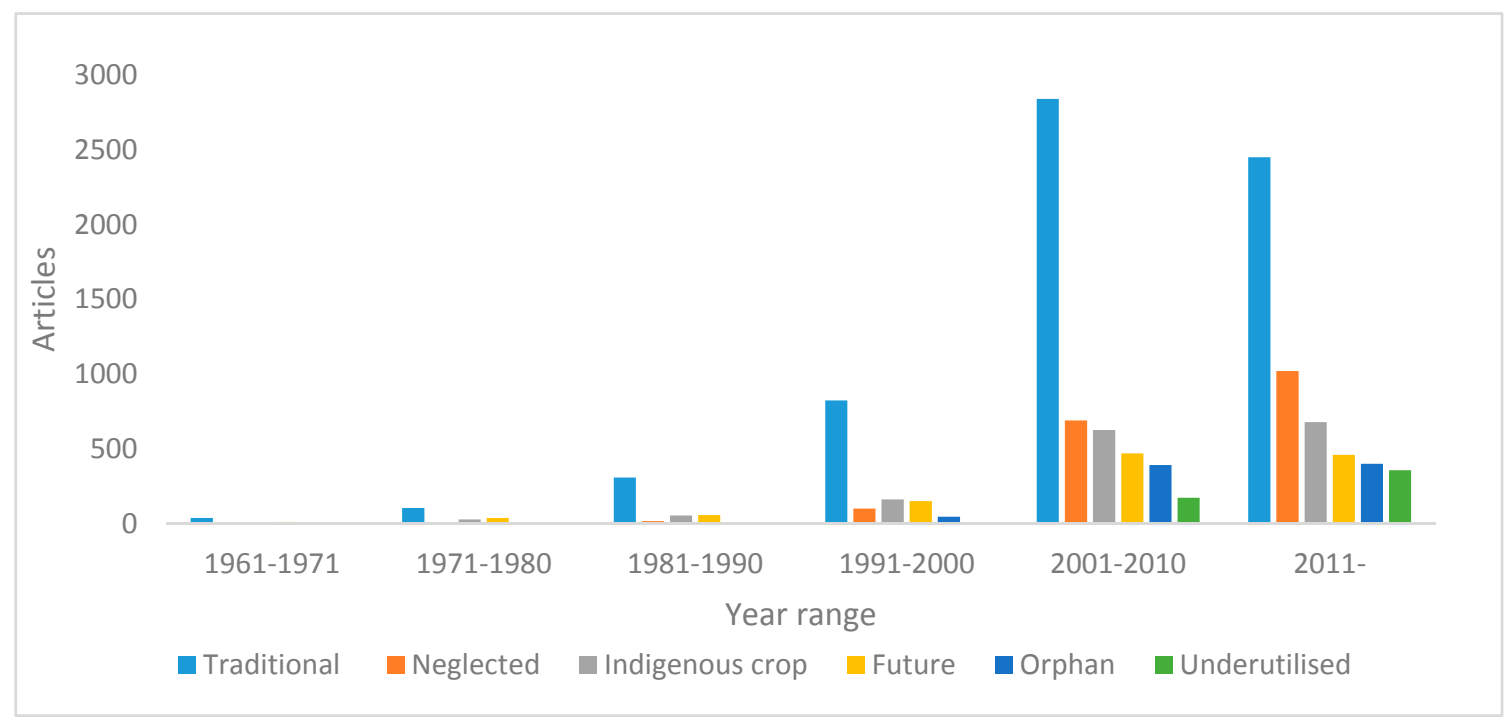

Figure 1. Articles across different time periods about South Africa that give reference to the terms traditional, neglected, indigenous, future, orphan and underutilised crop species.

By the early 1980s, it was recognised that the over-simplification of agriculture was contributing to increased risk for global crop production. Advocacy for adoption of sustainable farming systems and indigenous knowledge systems increased leading to the need to clearly define the concept of traditional/indigenous/neglected crops as indicated below:

Traditional crops refer to crops that are synonymous with a certain geographic location and have great cultural significance. They are traditional in the sense that they have been assimilated into the culture of communities. These crops are also often referred to as "landraces" with geographic and cultural importance thus creating spatial and temporal variations. Information concerning their husbandry has always been strongly tied to indigenous knowledge systems [2].

Indigenous crops refer to crop species that have originated from within the geographical area of interest. They are often characterised by limited development relative to their potential. The term "indigenous" has also often been used to refer to crops that may have originated elsewhere but have undergone extensive domestication locally thus giving rise to local variations, i.e., "naturalised/indigenised crops". The latter group of crops is also often referred to as traditional crops.

New or future crops refer to crops that previously did not have significant industrial importance due to low levels of utilisation but that may offer potential to spurn new value chains if corrective research and development actions are taken. 
Neglected crops are those crops that could have significant potential within geographic niche areas but have been marginalisation because of low social prestige, laborious methods of preparing them and low economic returns.

Orphan crops are typically not traded internationally but can play an important role in regional food security. Similarly, many of these crops have received little attention from crop breeders or other research institutions that can improve their production potential.

Underutilised crops may have considerable potential for use but this potential has barely been utilised. Often these crop species are globally distributed and have vast potential but their utilisation is currently confined to ecological niche areas. Underutilised crops are not limited to indigenous, indigenised or traditional crops and often vary depending on "where, when and by whom" [10].

Underutilised indigenous and traditional crops are crops that have originated in specific niche environments or those that have become "indigenised" over many years of cultivation and selection. These are crops that have not been previously classified as major crops, have previously been under-researched, currently occupy low levels of utilisation and are mainly confined to small-scale farming areas [11].

These definitions overlap, but it is clear that the concept of neglected and underutilised crop species has been used to refer to crop species that have significant potential as food and industrial crops but are marginalised, if not entirely side-lined, by researchers, breeders, policy makers, producers and traders. Consequently, they have poorly developed and understood value chains. They are non-commodity crops and belong to a large, biodiverse group of domesticated, semi-domesticated or wild species and in most instances, are locally adapted [12]. They are managed within traditional systems, use informal seed systems and involve a strong gender element [13]. Today, these crops are receiving increasing recognition because of their potential role in mitigating risk in agricultural production systems and promoting food security [14].

While the global trend in literature appears to be gravitating towards the adoption of the term "NUS", South African literature seemed to remain scattered among different terms. Of the publications considered for this review, less than 15 peer-reviewed articles that were published for South Africa used the term NUS. There is a need to align South African literature with emerging global trends. This will contribute to the increased visibility of local research outputs on the global stage as well as allow for archiving and consolidation of such outputs.

\section{Smallholder Agriculture in South Africa}

The agricultural sector is a dual economy characterised by a well-developed commercial agricultural sector and a less-developed, dynamic smallholder agricultural sector [15]. As of 2012, the commercial agricultural sector comprised about 40,000 farming units and these covered a production area of 82 million ha [16]. In contrast, the smallholder sector comprised more than 1.4 million small family farms that occupied less than 14 million ha. Communal agriculture is largely within the former homelands, which are characterised by degraded soils due to poor soil and water management practices [17]. Consequently, agricultural productivity has been declining over time [18].

Nevertheless, agriculture continues to play an important role in rural livelihoods and has potential to reduce poverty and food and nutrition insecurity $[19,20]$. The potential of smallholder farmers remains underdeveloped. They face numerous socio-economic and biophysical constraints mostly associated with low access to credit, poor soil quality, low water availability and poor access to seed of improved crop varieties. According to Statistics South Africa, it is in these areas where the prevalence of poverty and food and nutrition insecurity is highest [21]. It is in this context that neglected and underutilised crops hold significant prospects as they offer meaningful opportunities for sustainable development solutions under low input agricultural systems [4]. Therefore, the focus of this section is on smallholder farmers and identifying the role that underutilised crops play in rural landscapes. 


\subsection{Overview of Land Suitability}

South Africa's land suitability for agriculture was determined using the land capacity classification systems which groups land using physical properties (soil, terrain and climate) based on their capability to produce conventional food and pasture, not NUS. In all eight land classes (Figure 2), only $2 \%$ constitutes high potential areas (Classes 1 and 2) and is highly suitable for rainfed agriculture [22]. The majority of the land (70.5\%) has been classified (Classes 5-8) as unsuitable for rainfed crop production due to the combination of poor rainfall and poor soils. According to Paterson [23], many of the former homelands are found between Classes 4 and 7 indicating that these farming areas have a low agricultural potential.

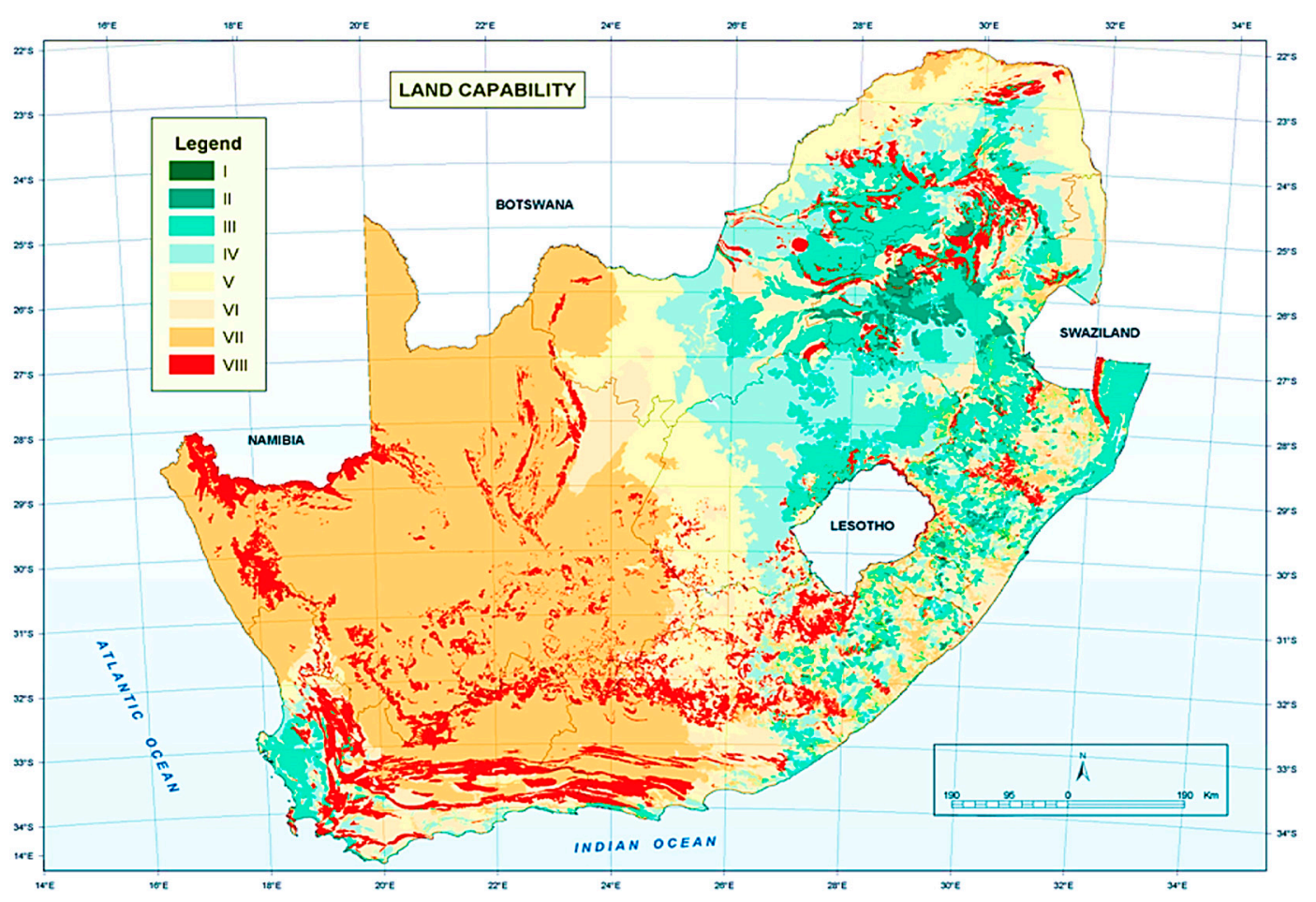

Figure 2. Land capability map for South Africa. I-No or few limitations, very high potential, very intensive agriculture $(0.2 \%)$; II-Slight limitations, high potential, intensive agriculture (1.8\%); III-Moderate limitations, moderate potential, moderate cultivation (10.6\%); IV—Significant limitations, low potential, light cultivation (11\%); V-Land with water limitations, low potential, moderate and light grazing; VI-Land with water limitations, low potential, intensive forestry, moderate and light grazing (15.5\%); VII-Severely limited by water and soil, very low potential, wildlife and light grazing (36.1\%) and VIII-Extremely limited by water and soil, not suitable for light grazing, low potential for wildlife (14.4\%). (Source: [24]).

Exclusion of NUS in the classification system has contributed to the promotion of a few major crops and the relegation of NUS. Several NUS continue to exist in niche agro-ecologies unsuitable for major crops. Modi and Mabhaudhi [1] hypothesised that the fact that NUS continue to survive in these harsh agro-ecologies lends credibility to the argument that they possess tolerance to several abiotic stresses such as drought and heat stress. Their continued existence, albeit with little support, highlights the limitations of the current land capability classification in acknowledging the natural agro-diversity of marginal agricultural lands. There is need for a paradigm to exploit the potential of existing agricultural lands under smallholder farming systems. Incorporating aspects of agro-ecology into the land suitability classification could broaden the scope of crops currently considered through a change in what is considered as "arable land" to "land arable for". Currently, land suitability refers to "arable land" and this encompasses land that can sustain crop production activities without over reliance on 
external resources. On the other hand, a shift to "land arable for" places emphasis on crops suitable for a particular agro-ecological zone. As such, land can be subdivided further according to the range of adaptable crop species; that is, appraising crop species for a given landscape. Thus, increasing what we may consider as arable land and directly increasing the recognition of NUS in smallholder farming systems. In addition, land arable for will also elevate existing food cultures, hence, a better understanding of food sovereignty within marginal communities.

While smallholder communities generally consider NUS as important, it remains difficult to identify their functional role within already existing farming and cropping systems. There have been attempts to establish the role of NUS at a regional level for the Southern African Development Community [25]. The SADC report showed that NUS played a multipurpose role within most rural communities. Their multipurpose nature also explained their continued preservation by such communities [25]. For South Africa, while there has been emerging interest on NUS, there has been limited attention on identifying their role within farming and cropping systems. This information is important as an initial step to establishing a baseline for promoting NUS.

\subsection{Overview of Farming and Cropping Systems in South Africa}

South Africa's farming and cropping systems are mainly determined by the agro-ecological zone in which they exist. Based on rainfall and temperature averages, the country can be sub-divided into six agro-ecological zones (AEZs), namely desert, arid, semi-arid, sub-humid, humid and super humid. The amount of rainfall decreases from east to west with super-humid region, which constitutes $2.8 \%$ of the country being situated in the east and arid and desert, which constitutes $47.4 \%$ in the west (Figure 3). The interior consists of both semi-arid and sub-humid AEZ. Therefore, the discussion on farming and cropping systems will focus on the suitability of farming and cropping systems for smallholder farmers within the semi-arid and sub-humid AEZ.
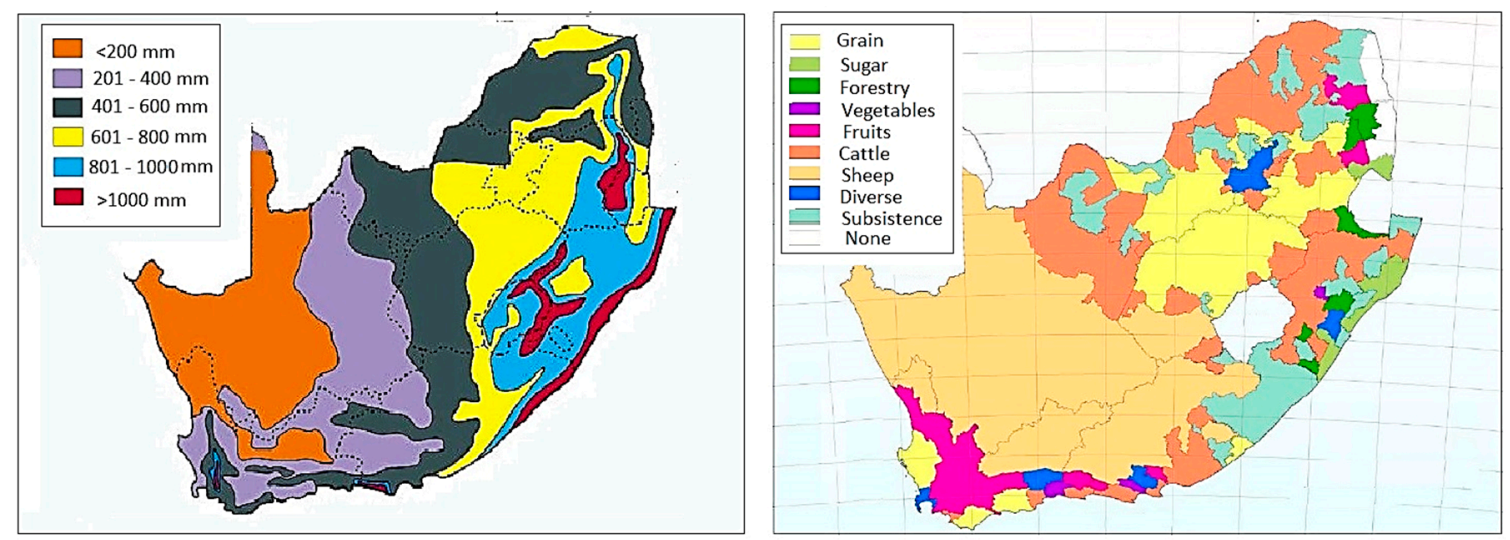

Figure 3. Rainfall distribution (Source: [24]) and farming systems (Source: [26]) across South Africa.

Many smallholder farmers in South Africa are resource constrained with poorly developed enterprises. Their main farming systems are agro-pastoral (Table 1), regardless of the AEZ, as livestock constitute an important cultural role $[27,28]$. The intensity of agro-pastoral organisation differs with AEZ and is influenced, primarily, by rainfall availability. In the semi-arid regions of the Eastern Cape Province, more than $90 \%$ of smallholder farmers have been observed to own a variety of livestock, including cattle, horses, donkeys, goats, pigs, sheep, chickens and turkeys. Less than $50 \%$ of smallholder farmers participated in field crop production $[29,30]$. This is consistent with the land suitability classification that placed much of these areas under Classes 4-6, suitable for pastoral activities and less suitable for rainfed agriculture. On the other hand, in the sub-humid area of the same province, livestock diversity was smaller and most of the smallholder farmers grow crops [31]. 
Table 1. Description of agro-ecologies and associated farming and cropping systems where many of the smallholder farmers are found in South Africa.

\begin{tabular}{|c|c|c|c|c|}
\hline $\begin{array}{l}\text { Agro-Ecological } \\
\text { Classification }\end{array}$ & Biome & Farming Systems & Cropping System & Observed NUS \\
\hline Sub-humid & $\begin{array}{c}\text { Grassland } \\
\text { savannah/savannah }\end{array}$ & $\begin{array}{l}\text { Agro-pastoral and } \\
\text { Mixed maize }\end{array}$ & Mixed maize & $\begin{array}{l}\text { Sorghum, millets, African eggplant (Solanum macrocarpon, S. aethiopicus and } \\
\text { S. anguivi), vegetable and grain cowpea (Vigna unguiculata), wild mustard } \\
\text { (Brassica carinata) and jute mallow (Corchorus olitorius) Chinese cabbage } \\
\text { (Brassica rapa L. subsp. Chinensis), pumpkin (Cucurbita maxima), various } \\
\text { Cucurbita spp., bitter watermelon (Citrullus lanatus (Thunberg) Matsum. } \\
\text { subsp. Lanatus), spider plant (Cleome gynandra L.) cassava (Manihot esculenta), } \\
\text { sweet potato (Ipomoea batatas), bambara groundnut (Vigna subterranea) and taro } \\
\text { (Colocasia esculenta) }\end{array}$ \\
\hline Semi-arid & $\begin{array}{c}\text { Nama } \\
\text { karoo/savannah }\end{array}$ & $\begin{array}{l}\text { Agro-pastoral and } \\
\text { Mixed maize }\end{array}$ & $\begin{array}{l}\text { Maize, sorghum and } \\
\text { millets }\end{array}$ & $\begin{array}{l}\text { Sorghum, millets, African eggplant, vegetable and grain cowpea, wild mustard, jute } \\
\text { mallow, Chinese cabbage, various Cucurbita spp., bitter watermelon, spider plant, } \\
\text { sweet potato, bambara groundnut, Fat hen (Chenopodium album), Spindle-pod } \\
\text { (Cleome monophylla), Jelly melon (Cucumis metuliferus), Devil's thorn } \\
\text { (Tribulus terrestris), Gallant soldier (Galinsoga parviflora), Yellow justicia (Justicia flava), } \\
\text { Stars talk (Oxygonum sinuatum), Sticky gooseberry (Physalis viscose), Purslane } \\
\text { (Portulaca oleracea), Coffee senna (Senna occidentalis), Black nightshade } \\
\text { (Solanum nodiflorum) and Giant bell flower (Wahlenbergia undulata) }\end{array}$ \\
\hline
\end{tabular}


Regardless of agroecology, maize is the dominant crop produced and this is linked with its status as a staple [32]. Mixed and maize monoculture (Table 1) are the dominant cropping systems [33-35]. Within these cropping systems, food crops such as beans (Phaseolus vulgaris), sweet potato (Ipomoea batatas), pumpkin (Cucurbita pepo) and butternut (Cucurbita moschata) are also produced. In Limpopo, KwaZulu-Natal and Mpumalanga, smallholder farmers grow sorghum and it is an important cereal crop with multipurpose functions. Many of the agricultural landscapes are modelled on commercial production systems and the productivity of maize and other food crops are low given the erratic and low rainfall, frequent droughts and poor soil fertility [36-38]. It could be that crop choices, i.e. crop types and/or species, may not be suited for the agro-ecology and does not support current efforts of aligning food sovereignty and food and nutrition security. Therefore, the crop choice should focus on including crops that are drought tolerant and adapted to low input agricultural systems. In this regard, certain NUS which are drought tolerant and nutrient dense have played a small but significant role within smallholder communities.

Several NUS are consumed across smallholder communities and these range from cereal, legume, root and tuber, and leafy vegetables. The popularity of leafy vegetables, also referred to as African Leafy Vegetables (ALVs), was attributed to their short growing season, high nutrient content, low agronomic requirements, drought tolerance, unique and acquired taste and their abundance in the wild [39-42]. More than 45 NUS have been documented to be in use $[1,15,39,43,44]$. Notably, the diversity of NUS was higher within the semi-arid region (Table 1) where they are collected and/or produced, and traded within informal markets. The potential of NUS under water scarcity in semi-arid areas has previously been established [2].

Most NUS are tolerant to several environmental stresses and thus should be promoted in marginal agricultural production areas. Their vast genetic pool presents an important sub-set of agro-biodiversity; therefore, supporting landscape diversity in marginal areas [10]. Promotion of NUS in smallholder communities should not seek to substitute current major crops; rather, it should focus on diversifying current cropping systems to minimise the current global cropping system characterised by low agro-biodiversity [10], whereby only five crops (maize, wheat, rice, potato and sorghum) account for more than $60 \%$ of daily calorific intake. There is a strong relationship between high agro-biodiversity and food and nutrition security through the increase in food choices, food availability and access [4]. Therefore, increased agro-biodiversity through the promotion of NUS can improve food choices, which will translate to improved food sovereignty and livelihoods of smallholder communities.

The role of NUS in the food consumption patterns in South African households is highly variable and depends on factors such as economic status, degree of urbanisation, distance to fresh produce markets and time of year [42]. It could be argued that consumption of NUS has always been a livelihood strategy by smallholder farmers located in marginal areas.

\section{Status of NUS in South Africa}

South Africa's population is expected to reach 65.5 million by 2050 [21], and the proportion of the population suffering from malnutrition will increase. To mitigate this challenge, more than $50 \%$ increase in food production is required [45]. Strategies suggested for increasing agricultural production include: (i) expanding area under cultivation; (ii) breeding for new high yielding varieties; and (iii) improved resource efficiency. South Africa has underutilised land largely located in the marginal areas, but agriculture is limited by water scarcity. Hence, the focus on resource use efficiency has been improving water use efficiency. A possible fourth option that could be considered to improve agricultural production is a focus on NUS. They have potential to: (i) expand land under cultivation; (ii) diversify germplasm for future crop improvement; and (iii) confer resource use efficiency (land and water). The fact that NUS remain underutilised creates an opportunity for the development of new value chains in support of rural agricultural development and food security. This can be achieved through the research value chain, including breeding/crop improvement, production, agro-processing, 
and marketing. The gaps within the research value chain of NUS and possible strategies to overcome them are suggested below.

\subsection{Indigenous Fruit Trees}

Natural forests and homesteads are important sources of indigenous or "wild" fruit tree crops. These indigenous fruit trees are essential for food security, nutrition and health, social and economic welfare of rural communities who typically sell them on road sides and urban markets to generate income [2]. Within the context of South Africa, indigenous or "wild" fruit tree crops are fruit types that occur naturally in the wild and form part of the indigenous food crops basket (i.e., cereals, legumes, root and tuber, leafy vegetables and fruits). Based on our definition for indigenous crop species, indigenous fruit trees (IFTs), as understood in this paper, are taken to include both indigenous and traditional fruit tree crops. The nutrient profiles of several IFTs have been observed to be similar to that of exotic fruits with the exception that IFTs often have higher levels of Vitamin C. This would confirm current generalisations about the nutritional value of IFTs and their ability to contribute to dietary diversity and nutrition of poor rural households [46,47]. However, research on IFTs lags that of commercial fruit crops with an obvious bias towards exotic fruits in well-managed orchards. Indigenous fruit trees have scarcely achieved any level of international recognition in commodity markets and research agenda [48]. However, the growing body of literature on genetics, conservation and production of IFT within the greater Southern African region [48-52], which continues to increase the recognition of IFT within rural farming systems, must acknowledged and further supported. With respect to South Africa, the Department of Agriculture Forestry and Fisheries [53] published and support work on a list of seven common IFTs. These were marula, red milkwood (Mimusops zeyheri), mobola plum (Parinari curatellifolia), wild medlar (Vangueria infausta), num-num, Kei-apple and monkey orange (Strychnos spinosa) (Table 1). Most of these IFTs' major growing areas are poor rural provinces such as the Eastern Cape, Limpopo and KwaZulu-Natal Provinces [53]. The continued presence of IFTs in poor rural areas confirms Packham's [52] observations that rural farmers valued IFTs and tended not to clear them even when they cleared new land for agricultural purposes.

\subsection{Underutilised Crops Value Chains}

Any agricultural product needs to pass through a number of stages from the producer through to the consumer. In-between, there are a variety of primary and supportive activities to add value (Figure 4). Primary activities are product and market related while support activities are those that are related to infrastructure, technology, research and development, and human resources. The "value chain" thus refers to cluster and sequence of activities involved in the production up to the marketing of a product (Figure 4) from conception, through the different phases of production delivery to final consumers, and final disposal after use [54]. By analysing the downstream and upstream information along the value chain, NUS could be clearly recognised and enhanced.

In the context of rural agricultural development, value-chain approaches have since become a popular strategy to encourage greater participation in national and international markets. Such a strategy has also been proposed for the promotion of NUS [10]; however, little has been done to develop sustainable value chains. Value chains of NUS have been described as being immature with few activities and actors. To ensure successful translation of NUS as food and commodity crops, there is need to identify actors and their key roles. Figure 4 proposes a simple food value chain. It outlines the "who", "when" and "how" considerations to guide upscaling NUS value chains. Support activities play a pivotal role in identifying and enhancing "value" that is to be added, thus creating an incentive for the involvement of a broader spectrum of actors. This set of activities has been coined "research value chain". Lack of an explicit focus on the supportive role of research and development may partly explain the slow progress in the development of NUS value chains. The need for research and development is particularly true since much information remains in indigenous knowledge systems. A clear and targeted research and development agenda could unlock the potential of NUS. This can be 
done by employing the same techniques used in the development of major crops such as biotechnology, crop genetics and breeding, agronomy and agro-processing.

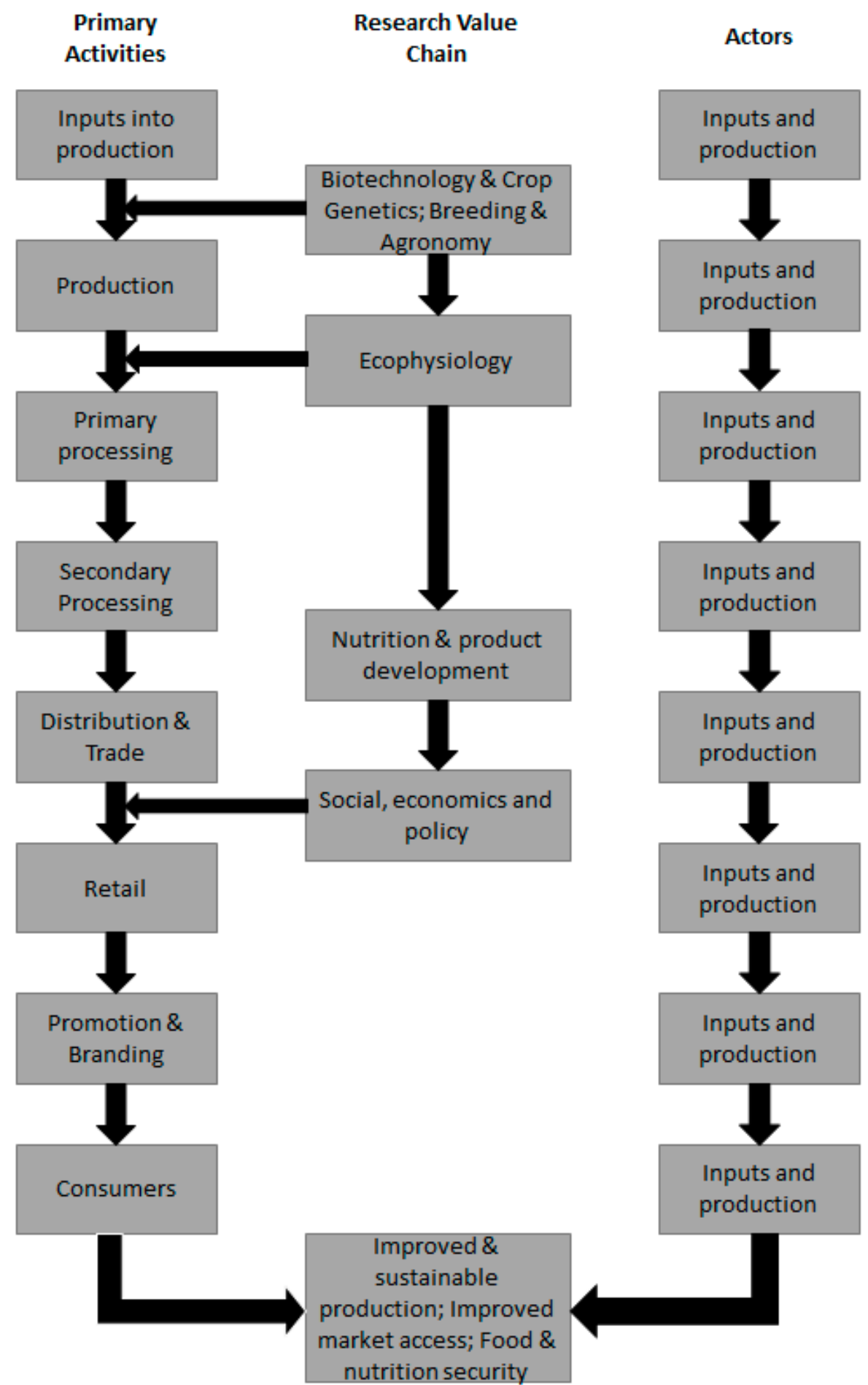

Figure 4. Value chain of neglected and underutilised crops indicating primary and support activities, and actors involved during the primary activities.

\subsubsection{Biotechnology, Crop Genetics and Breeding}

Plant genetic resources (PGR) for food and agriculture play an ever-increasing role in ensuring food security and economic development under marginal farming systems. Resilient and sustainable 
farming systems must be rich in high agro-biodiversity. As an integral component of agro-biodiversity, NUS represent an important gene pool that could be used to: (a) broaden the current gene pool; (b) facilitate future breeding and crop improvement; and (c) expand agriculture into marginal areas characterised by water and nutrient stress. Current breeding efforts are now shifting to identifying crop wild relatives, which are mostly NUS, as sources of germplasm for new breeding programmes. This shift confirms reports that NUS can serve as a primary source of beneficial traits for major crop species [55-58]. However, the potential of NUS as PGR is currently untapped as they are poorly represented in national gene bank collections and most research agenda. A starting point could be to collect the range of local NUS for South Africa and to characterise them as a source of germplasm.

Considering the need for an immediate intervention concerning increasing agro-biodiversity, NUS form a significant source of accessible PGR due to their intra- and inter-genetic abundance, which can be found across different geographic scales. In South Africa, genetic diversity of NUS remains anecdotal although the country is considered as a "NUS hotspot". This is in line with the country's status as megadiverse. Due to the poor documentation of genetic diversity of NUS in the country, it is not clear how much is available and how much has already been lost. There is need to assess the current genetic diversity for NUS for the purpose of their conservation, development and exploitation.

While NUS possess several attributes that could drive rural agricultural development, the lack of information creates a disincentive for their investment and entry into formal market systems. According to Dawson [59], the genetic variations within NUS exhibit partially defined semi- or incipient domestication with superficial characterisation owing to the degree of intra-species heterogeneity. As such, the diversity of benefits provided by NUS often accompanies equally diverse shortcomings that often influence their use in mainstream agriculture.

Biotechnology tools, together with conventional crop genetics and breeding activities, have been employed for the rapid genetic improvement of major food crops and can be used for underutilised crops. In South Africa, the national Bio-economy Strategy's [60] objective for agriculture is to strengthen agricultural biosciences innovation to ensure food security, enhance nutrition and improve health, expand and intensify sustainable agricultural production and processing. Within the strategy, it is recognised that unlocking the value of indigenous crops, coupled with consumer demand for "natural" products, presents opportunities for South Africa to capitalise on its biodiversity and capture niche markets [60].

\subsubsection{Agronomy Consideration for the Production on NUS}

Although NUS are considered adaptable to marginal lands a major factor, affecting their uptake by smallholder farmers is the limited knowledge regarding their production. Several authors have pointed out issues of seed dormancy, poor crop establishment, low yield and poor storage, susceptibility to pests and diseases and the presence of anti-nutrient factors (ANFs) [61-64]. Although cultivating low input crops like NUS in marginal lands presents huge advantages, parallel disadvantages may have elevated the promotion of major crop species within smallholder farming systems. Mabhaudhi [65] argued that the poor establishment of bambara groundnut may partly explain why farmers have moved away from cultivating it. To exploit the full potential of NUS, and promote their adoption into existing cropping systems, aspects of crop and soil management strategies need to be formulated.

Generating information regarding plant densities, fertiliser application rates, planting dates, water requirements, weeding, pest and disease control, and harvest techniques is important for upscaling production of NUS. This is especially important considering that the efficient use of limited resources such as water can be enhanced through optimum agronomic practices [66]. Combining optimum agronomic practices with improved varieties generated from breeding and biotechnology could help farmers to realise significant increases in yield of NUS. In South Africa, there has been some progress made on assessing agronomic practices and developing best practice recommendations for production of NUS, especially leafy vegetables [42,67]. For example, research into ALVs has covered many aspects of their agronomy and agro-processing. While efforts are being made for cereal, legume, root, and tuber 
crops, very limited information remains available. A synergy of crop and soil management practices is required to increase yield potential of NUS, especially if they are to be a source of food and nutrition security for smallholder farmers residing in sub-optimum environments. Therefore, further research is required on the various agronomic aspects of NUS in South Africa.

\subsubsection{The Ecophysiology of NUS}

The environment in which smallholder farmers reside is characterised as low potential for rainfed agriculture. Climate variability and change is worsening the agricultural outlook due to increased incidences of drought and floods. The 2015/2016 drought affected many smallholder farmers, as they had no access to water for irrigation or knowledge of rainwater harvesting and conservation techniques. The lack of diversity and drought tolerant crops within their cropping system led to a collapse of the system and exposed millions to hunger. The promotion of NUS, which have been shown to be highly adaptable to harsh environment, can aid in improving resilience within these systems.

Ecophysiology is the relationship existing between living beings and their physical and biotic environment. The productivity of food crops depends on the ability to adapt to environmental and climatic uncertainty. It is also interpreted as morphological, anatomical, and physiological as well as biochemical adaptations that ensure the continued survival of a species in a given environment. Several studies in South Africa have alluded to the advantages observed in NUS grown under resource limitations as being related to good ecophysiological responses [1,43,66]. For instance, Mabhaudhi [65] stated that stable yields observed in bambara groundnut grown in different water regimes were associated with reduction in canopy size and maintenance of high stomatal conductance. Cowpea was observed to shed leaves and assume a state of growth arrest under prolonged low water availability and resume growth when soil water availability improves [68]. While most NUS have been praised for their ability to grow well under resource limitations like water, and are resilient to weather extremes, there is insufficient empirical and comparable data to support these claims, especially within the South African context. The only limitation, perhaps, may be that work done so far has not focused on particular NUS. Rather, it has looked at a range of NUS. Whilst this may be sufficient for building a body of knowledge on NUS, there is a need to identify certain priority crops that can be focussed on. This will allow for exemplar NUS to be identified, studied and taken through the entire value chain. Success stories for a few NUS may have the impact of shifting attention to NUS.

\subsubsection{Nutrition and Product Development}

Food security exists when every person has access to sufficient food to sustain a healthy and productive life, where malnutrition is absent, and where food originates from efficient, effective, equitable and low-cost food systems that are compatible with sustainable use of natural resources [42,45]. While South Africa may be food secure as a country, large numbers of households remain food insecure [45]. Observed levels of malnutrition have been associated with limited food diversity observed within rural communities. Diets are dominated by starch-based foods and lack adequate amounts of protein, vitamins and other mineral nutrients. This has been associated with limited food sources and choices [42]. Kennedy et al. [69] stated that dietary diversity is an integral component of a quality diet; both diversity and quality are key to achieving food and nutritional security, as well as food sovereignty [70]. As a way of improving household food and nutrition security for smallholder farmers, NUS have been identified as a sustainable and viable means.

The nutritional value of a food crop implies the quantity, range and quality of energy (calories), vitamins, minerals and phytochemicals. Several studies in South Africa have evaluated nutritional value of NUS and reports allude to the fact that they supersede that of related conventional food crops. The micronutrient content of NUS has been shown to be species specific suggesting that not all NUS may be nutrient dense. This highlights the need to identify and prioritise specific NUS that are drought tolerant and nutrient dense. In general, African leafy vegetables contain substantial amounts of carotenoids (lutein and $\beta$-carotene), iron, folate, riboflavin and calcium [71]. Many of the known 
underutilised legumes (e.g., Mucuna spp., Canavalia spp., Sesbania spp.) have higher amounts of protein, essential amino acids, polyunsaturated fatty acids, dietary fibre, and essential minerals and vitamins relative to other common legumes, along with the presence of beneficial bioactive compounds [72]. However, dark green leafy vegetables are known to contain oxalates, phytates and nitrates, and ANFs such as total free phenolics, tannins, L-DOPA, trypsin inhibitor activity and phytohaemaglutinating activity [73].

Although NUS may be nutrient dense, the presence of ANFs and the inability to process and add value to NUS may act as a deterrent for their investment. Depending on the consumer preferences retaining or eliminating these compounds could be facilitated given the appropriate agro-processing technique. To reposition the neglected crops species so that they have an equal standing in national and global markets, there is need to come up with agro-processing techniques that will add value and relevance to the product.

\subsection{Potential of NUS in Smallholder Farming Systems}

South Africa is classified as semi-arid and its water profile is rapidly moving from water scarce to water stressed [74]. The country's annual average rainfall fluctuates around $500 \mathrm{~mm}$, which is far below the world's average of $860 \mathrm{~mm}$ per annum [1]. Rainfall is unevenly distributed, with about $50 \%$ of the rain falling on $15 \%$ of the land [23]. It is in most of the remaining $85 \%$ of the country where smallholder farming communities are concentrated [23]. It is in the same areas where there are high incidences of food insecurity, malnutrition and poverty. Crop productivity is low and there are significant yield gaps; this mainly due to dependence on rainfed agriculture. The low productivity, perpetuated by low food choices, exposes farmers in these areas to chronic food insecurity.

Part of the solution to this could involve including crops that are drought tolerant, with low water requirement and adapted to low input systems as part of the crop choice. It is in this context that the inclusion of NUS into crop systems of smallholder farmers should be promoted as they have immense potential to mitigate nutritional and water constraints. Their inclusion into existing cropping systems in marginal areas may increase overall resilience of cropping systems through increasing agro-biodiversity. In addition, by growing socially, culturally and ecologically suitable crops, this would contribute to food sovereignty. In this regard, they could be used to contribute towards sustainable intensification of rural cropping systems. Their inherent diversity also has potential to broaden rural food baskets, which currently lack dietary diversity. Lastly, the fact that NUS value chains are underdeveloped creates opportunities for developing autonomous pathways out of poverty through promoting them in rural areas [4]. In this regard, they can contribute to employment and wealth creation through opening new of opportunities.

\section{Opportunities and Challenges for NUS in South Africa}

\subsection{Opportunities}

South Africa's food and agricultural-related policies provide opportunities to include NUS in national development planning. While increasing the productivity of major cereal crops remains a continuous objective, policies have broadened their scope to include the promotion of NUS as a cornerstone for increased dietary diversity. For example, the National Policy on Food and Nutrition Security (NPFNS) [75] advocates for promoting research, development and utilisation of NUS. The policy aims to promote and diversify food production by promoting the utilisation of NUS within farming systems dominated by cereal based cropping systems. They are now considered as a significant complement to "major" food crops and serve to prevent malnutrition, which is prevalent in poor rural communities. The NPFNS, together with other agricultural developmental polices, acknowledge that increasing dietary diversity is an important strategy to improve nutrition and health. This is consistent with Sustainable Development Goals (SDGs) 1-3 that address poverty, food and nutrition security, and health, respectively. Their incorporation into existing cropping systems presents 
a win-win situation for increased agro-biodiversity, dietary diversity, food sovereignty and food and nutrition security.

Smallholder farmers are often characterised as being resource poor lacking necessary financial, functional and structural support for rainfed agriculture. In addition, AEZs in which smallholder farming communities reside are mostly unsuitable for rainfed production. Additionally, it has been observed that climate variability and change is increasing risk in rainfed systems due to shifting seasons, increased incidences and duration of dry spells and flash floods [76-79]. Several NUS have been observed to require fewer external inputs for rainfed production and, while they may yield less than major crops, they are relatively stable across different environmental conditions, especially extreme weather conditions such as drought and heat stress. Thus, NUS are low input alternatives that could improve productivity in semi-arid areas and under climate change. Indigenous food trees have the potential to contribute to: (i) food and nutrition security; (ii) employment creation; (iii) gender mainstreaming; and (iv) building resilience.

Indigenous fruits crops such as wild plum, marula, wild apricot, monkey orange, amatungulu/ num-num, baobab, Kei-apple and red gherkin are rich in sugars, essential vitamins, minerals, protein, carbohydrates and oils, which are essential for human nutrition [80]. The harvesting and use of IFTs has long been associated with women and their household roles of feeding the family as well as selling them on the market and promotes greater food sovereignty. The promotion of IFTs in rural areas could open more economic opportunities for women and youths in poor rural areas. Most of them are uniquely adapted to the harsh ecological environments that typify these areas. This lends them to being ideal for building resilience.

An agro-ecology based approach for land use classification would contribute to including NUS as part of the mainstream crop choice. The agro-ecology-based approach would allow for the realisation and acknowledgement of the role that NUS could play, especially in semi-arid and arid areas. The link between food sovereignty, agro-ecology, farming and cropping systems and NUS offers a novel approach to promoting NUS [70]. It also creates opportunities for upscaling the work on NUS from just South Africa, but to the southern African region as it could create opportunities for regional planning for promoting underutilised crops within similar agro-ecologies. In addition, the paradigm shifts towards agro-ecology based systems converge narratives on food sovereignty within the discourse of food security.

As it is, the premise of food sovereignty speaks towards the inclusion of NUS within traditional and modern agrarian systems. Therefore, NUS provide opportunities to develop a food sovereignty models within marginal farming systems. Underutilised crops can link cultural, socio-economic and agro-ecological food networks, thus supporting efforts to improve food security within dynamic food systems present in rural communities. The participation of NUS in mainstay food networks maximise comparative advantages with regards to market access, diversity and stability. In addition, continued promotion will facilitate the exchange, trade and ultimately commercialisation of NUS within the context of sovereign food systems.

The production and marketing of NUS present opportunities for linking rural farmers to national and international niche markets. An example of such is the case of taro (amadumbe), an underutilized crop, which has been targeted for research and promoted in KwaZulu-Natal, South Africa. As a result of these focused efforts on the crop, taro is now available in major retail outlets and has created a source of income for rural farmers who produce it organically for supply to these major retail outlets. Modern technologies such as biotechnology and innovative agro-processing technologies could assist to transform NUS into diverse products, making them more palatable and extend their shelf-life. For example, in the case of taro, this could be the development of new higher yielding varieties, and developing appropriate post-harvest handling and storage protocols as well as developing products from taro. This would create new opportunities for smallholder communities to participate in NUS value chains. The promotion of drought tolerant and nutrient dense NUS also offers unique opportunities to address several of the SDGs as follows: 
- Achieving dietary diversity: SDG 1: end poverty in all forms everywhere; SDG 2: end hunger, achieve food security and improved nutrition and promote sustainable agriculture; and SDG 3: ensure healthy lives and promote well-being for all ages.

- Employment creation: SDG 1: end poverty in all forms everywhere; and SDG 8: promote sustained, inclusive and sustainable economic growth, full and productive employment and decent work for all.

- Mitigating drought and water scarcity: SDG 15: protect, restore and promote sustainable use of terrestrial ecosystems, sustainably manage forests, combat desertification, and halt and reverse land degradation and halt biodiversity loss.

\subsection{Challenges}

The absence of well-developed, supported and tested value chains is a challenge for the promotion and utilisation of NUS. Empirical information required to formulate a sustainable food value chain is largely anecdotal and inconsistent. There are significant gaps about literature concerning underutilised crops. This is mostly attributed to the lack of focused research and development initiatives and infrastructure for upscaling and marketing NUS. This has created challenges in formulating strategies for scaling up production of NUS and their products within smallholder farming communities. To expand the scale of production, efficient technologies must be developed for manufacturing, storage and processing.

The social perceptions attached to NUS have led to their low adoption into existing cropping systems. They are often perceived as being "low status", "backward" or "old fashioned" or "poor man's" crops. Consequently, younger generations partaking in smallholder farming activities often shun NUS. The social barriers regarding the promotion and uptake of NUS could be that information on their benefits is not easily accessible. Modern technologies need to be promoted to incentivise and increase awareness among younger generations.

The lack of robust empirical and comparable information describing basic aspects of NUS such as their agronomy and ecophysiology means that a lot is left is to anecdotal evidence [4]. This could act as a disincentive for governments and major funders to invest in their research and development. According to Padulosi [12], the main agronomic challenges affecting the promotion of NUS include: (i) insufficient, and at times lack of, propagation material and seed owing to informal seed market systems; (ii) insufficiently trained human resources who possess the technical aspects of producing NUS; and (iii) poor support from research and development into best management options with regards to the crop, soil, fertiliser and, pest and weed. This analysis is consistent with the status of NUS in South Africa.

\section{Recommendations on Identified Research Gaps}

The current study applied a value chain approach to appraise the status of NUS in South Africa. Specifically, the study reviewed crop production, breeding, ecophysiology and product development as aspects of the NUS research value chain. Based on this assessment, the following research gaps were identified.

- Land use classification: There is need for a paradigm shift in the current approaches that are used for land use classification, which continue to exclude NUS. Therefore, there is need on crop suitability mapping and fitting NUS into specific agro-ecologies. A current gap to this would be the need to develop crop specific factors for NUS, that can be used to describe them as part of crop suitability mapping.

- Agronomy: Whilst there have been strides in describing the agronomy of various NUS, there are still major gaps with regards to issues such as optimum planting densities, pest and disease management and fertiliser management, among other things. This lack of knowledge makes it challenging to promote NUS as there are often no production guidelines describing the best management practices for NUS. 
- Ecophysiology: There are reports of several NUS possessing tolerance to key abiotic stresses such as drought and heat stress. However, much of this information remains anecdotal and patchy. There is therefore a need to generate more empirical information on the ecophysiology of NUS. This should be linked to agro-ecologies in order to support the crop suitability mapping/land use classification.

- Post-harvest handling and storage: For most NUS, there is a total lack of documented appropriate post-harvest handling and storage practices. This means, even when farmers are able to produce these crops, there may be significant post-harvest losses. Developing appropriate post-harvest handling and storage practices would also contribute towards developing best management practices for NUS.

- Nutritional value: Similar to agronomic aspects of NUS, there is lack of comparable information on the nutritional value of NUS. Addressing this knowledge gap will go some way in highlighting the nutritional benefits often associated with use of NUS and their promotion as healthy alternatives.

- Marketing: Access to markets remains an obstacle for NUS. Existing markets have been developed to support the major crops based on the existing paradigm that supports a few major food crops. There is need for research on market analyses to ascertain opportunities for mainstreaming or disrupting existing markets to allow for NUS' inclusion. Such research should also consider possibilities the feasibility of developing new niche markets specifically for NUS. The latter paradigm would align with developing new value chains for NUS.

- Product development: Currently, there are few products developed using NUS. Research on product development would also create new uses and markets for NUS and add to the new paradigm on their greater value and inclusion.

- Indigenous knowledge: Much of the knowledge on NUS is in the form of indigenous knowledge. This is perhaps the most important gap in research. The on-going erosion of indigenous knowledge is inadvertently contributing to genetic knowledge and decline in utilization of NUS as knowledge on the conservation, cultivation and utilization is being lost. The question is, how do we document this indigenous knowledge, preserve it, and ensure that it is reflected in the current and emerging discourse on NUS? This would also include developing models for access-benefit sharing to ensure that communities that have historically conserved these NUS are not side-lined in the development of NUS and that their contribution as farmer scientists is recognized.

The current review also noted that there is need for greater coordination of efforts and resources allocated to NUS research. In this regard, in addressing these gaps, there is need to identify a few NUS that offer potential for success, with regards to developing their value chains, and focusing on addressing the research gaps on those particular NUS. This would provide case studies of successes with promoting NUS and commercializing them, which would act as a powerful motivation for increasing investments in NUS. Thus, another gap to be addressed in this regard would be the identification of such NUS that show the greatest potential for success and should be prioritized.

\section{Conclusions}

Despite major strides in underutilised crops research, they remain marginalised in mainstream agriculture. The fact that most underutilised crops are drought tolerant and nutrient dense makes them an important resource for addressing key challenges of improving food and nutrition security under water scarcity, and in a changing climate. There is a need to consolidate the research that has been done to ensure large-scale impact and beneficiation. There is an urgent need for greater investments in NUS research and development to unlock potential value chains. This calls for a paradigm shift with regards to how research is currently prioritised and funded, a system that has favoured the major crops that are aligned to industrial agriculture. This shift should also include revising the existing land use classification and introducing an agro-ecology based land use classification system, which would allow for the inclusion of NUS in the crop choice and food networks. This should be matched with identifying 
and prioritising a few underutilised crops that have the greatest potential for success with respect to addressing food security and sovereignty, climate change adaptation and improving rural livelihoods. Adopting a value chain approach to underutilised crop research and development offers significant potential for developing new and autonomous pathways for sustainably increasing production and alleviating rural poverty. In the absence of clear strategy and innovative forward-looking policies, the status of NUS will remain unchanged.

Acknowledgments: The Water Research Commission of South Africa is acknowledged for initiating, funding and directing this project through WRC Project No. K5/2603//4 "Developing a research agenda for promoting underutilised, indigenous and traditional crops".

Author Contributions: Tafadzwanashe Mabhaudhi and Albert Modi had the original idea for the article and carried out the conceptualization of the article. Tafadzwanashe Mabhaudhi and Vimbayi Chimonyo then led the write-up of the manuscript and all co-authors read and revised the manuscript.

Conflicts of Interest: The authors declare no conflict of interest.

\section{References}

1. Modi, A.T.; Mabhaudhi, T. Water Use and Drought Tolerance of Selected Traditional and Indigenous Crops; Final Report of Water Research Commission Project K5/1771/ /4; Water Research Commission: Pretoria, South Africa, 2013; ISBN 978-1-4312-0434-2.

2. Chivenge, P.; Mabhaudhi, T.; Modi, A.; Mafongoya, P. The Potential Role of Neglected and Underutilised Crop Species as Future Crops under Water Scarce Conditions in Sub-Saharan Africa. Int. J. Environ. Res. Public Health 2015, 12, 5685-5711. [CrossRef] [PubMed]

3. Mabhaudhi, T.; Chibarabada, T.; Modi, A. Water-Food-Nutrition-Health Nexus: Linking Water to Improving Food, Nutrition and Health in Sub-Saharan Africa. Int. J. Environ. Res. Public Health 2016, 13, 107-121. [CrossRef] [PubMed]

4. Mabhaudhi, T.; O'Reilly, P.; Walker, S.; Mwale, S. Opportunities for Underutilised Crops in Southern Africa's Post-2015 Development Agenda. Sustainability 2016, 8, 302. [CrossRef]

5. Spreeth, M.; Slabbert, M.; De Ronde, J.; Van den Heever, E.; Ndou, A. Screening of Cowpea, Bambara Groundnut and Amaranthus Germplasm for Drought Tolerance and Testing of the Selected Plant Material in Particpatation [sic] with Targeted Communities; WRC Report No. 944/1/04; Water Research Commission: Pretoria, South Africa, 2004; ISBN 1-77005-184-8.

6. Water Research Commision (WRC). Knowledge Review 2013/14; WRC: Pretoria, South Africa, 2014.

7. Water Research Commision (WRC). Water Use and Nutritional Water Productivity of Food Crops for Improved Nutritiona and Human Health for Poor Rural Households; Project Number K5/2493//4; WRC: Pretoria, South Africa, 2016.

8. Modi, A.T.; Mabhaudhi, T. Determining Water Use of Indigenous Grain and Legume Food Crops; Final Report of Water Research Commission Project K5/2274/ /4; WRC Report No. TT710/17; WRC: Pretoria, South Africa, 2017.

9. Blum, A. Stress, strain, signaling, and adaptation-Not just a matter of definition. J. Exp. Bot. 2016, 67, 562-565. [CrossRef] [PubMed]

10. Padulosi, S.; Hodgkin, T.; Williams, J.T.; Haq, N. Underutilized Crops: Trends, Challenges and Opportunities in the 21st Century; Ngels, J., Rao, V., Jackson, M., Eds.; CAB International: Wallingford, UK, 2002; ISBN 9780851995229.

11. Azam-Ali, S.N. Fitting underutilised crops within research-poor environments: Lessons and approaches. S. Afr. J. Plant Soil 2010, 27, 293-298. [CrossRef]

12. Padulosi, S.; Thompson, J.; Rudebjer, P. Fighting Poverty, Hunger and Malnutrition with Neglected and Underutilized Species: Needs, Challenges and the Way Forward: Neglected and Underutilized Species; Bioversity International: Rome, Italy, 2013.

13. Dansi, A.; Vodouhè, R.; Azokpota, P.; Yedomonhan, H.; Assogba, P.; Adjatin, A.; Loko, Y.L.; Dossou-Aminon, I.; Akpagana, K. Diversity of the Neglected and Underutilized Crop Species of Importance in Benin. Sci. World J. 2012, 2012, 1-19. [CrossRef] [PubMed]

14. Padulosi, S.; Hoeschle-Zeledon, I. Underutilized plant species: What are they? LEISA -LEUSDEN- 2004, 20, 5-6. 
15. Wenhold, F.F.; Faber, M.; van Averbeke, W.; Oelofse, A.; van Jaarsveld, P.; Jansen van Rensburg, W.; Van Heerden, I.; Slabbert, R. Linking smallholder agriculture and water to household food security and nutrition. Water SA 2007, 33, 327-336.

16. Hoffmann, T.; Todd, S.; Ntshona, Z.; Turner, S. Land degradation in South Africa. In A National Review of Land Degradation in South Africa; Hoffman, M., Todd, S., Ntshona, Z., Turner, S., Eds.; South African National Biodiversity Institute: Pretoria, South Africa, 2014.

17. Mandiringana, O.T.; Mnkeni, P.N.S.; Mkile, Z.; Van Averbeke, W.; Van Ranst, E.; Verplancke, H. Mineralogy and fertility status of selected soils of the Eastern Cape Province, South Africa. Commun. Soil Sci. Plant Anal. 2005, 36, 2431-2446. [CrossRef]

18. Giller, K.E.; Witter, E.; Corbeels, M.; Tittonell, P. Conservation agriculture and smallholder farming in Africa: the heretics' view. Field Crops Res. 2009, 114, 23-34. [CrossRef]

19. Governmant of South Africa; Government of South Africa Nine-Point Plan. Available online: http:/ / www. gov.za/issues/nine-point-plan (accessed on 7 August 2016).

20. National Planning Commission National Development Plan Vision 2030. Available online: http:/ / www.gov. za/issues/national-development-plan-2030 (accessed on 30 August 2017).

21. STATSSA Statistics South Africa. Available online: http:/ / cs2016.statssa.gov.za/ (accessed on 30 August 2017).

22. Department of Agriculture Forestry and Fisheries (DAFF). South African Agricultural Production Strategy. Available online: http:/ / www.nda.agric.za/docs/sectorplan/sectorplanE.htm (accessed on 30 August 2017).

23. Paterson, G. The "Land Question" from the Point of View of the Land. NEWS E ANALYSIS I Politicsweb. Available online: http:/ / www.politicsweb.co.za/news-and-analysis/the-land-question-from-the-pointof-view-of-the-la (accessed on 4 August 2016).

24. Collett, A. Impact of Geospatial Planning on the Agricultural Sector-EE Publishers. Available online: http: / /www.ee.co.za/article/impact-geo-spatial-planning-agricultural-sector.html (accessed on 2 September 2017).

25. Mabhaudhi, T.; O'Reilly, P.; Walker, S. The Role of Underutilised Crops in Southern African Farming Systems: A Scoping Study; Centre for Coordination of Agricultural Research and Development for Southern Africa: Gaborone, Botswana, 2016.

26. Cloete, S.; Olivier, J.; Sandenbergh, L.; Snyman, M. The adaption of the South Africa sheep industry to new trends in animal breeding and genetics: A review. S. Afr. J. Anim. Sci. 2015, 44, 307. [CrossRef]

27. Nethononda, L.O.; Odhiambo, J.J.O.; Paterson, D.G. Land suitability for specific crop ranges using dynamic land suitability evaluation guidelines for small-scale communal irrigation schemes. Bulg. J. Agric. Sci. 2014, 20, 1349-1360.

28. Waha, K.; Müller, C.; Bondeau, A.; Dietrich, J.P.; Kurukulasuriya, P.; Heinke, J.; Lotze-Campen, H. Adaptation to climate change through the choice of cropping system and sowing date in sub-Saharan Africa. Glob. Environ. Chang. 2013, 23, 130-143. [CrossRef]

29. Mapiye, C.; Chimonyo, M.; Dzama, K.; Raats, J.G.; Mapekula, M. Opportunities for improving Nguni cattle production in the smallholder farming systems of South Africa. Livest. Sci. 2009, 124, 196-204. [CrossRef]

30. Musemwa, L.; Mushunje, A.; Chimonyo, M.; Fraser, G.; Mapiye, C.; Muchenje, V. Nguni cattle marketing constraints and opportunities in the communal areas of South Africa: Review. African J. Agric. Res. 2008, 3, 239-245.

31. Chimonyo, V.G.P. An evaluation of stress tolerant open pollinated maize varieties across selected environments in the Eastern Cape province, South Africa. Master's Thesis, University of Fort Hare, Alice, South Africa, December 2012.

32. Gilimani, B.M. The Economic Contribution of Home Production for Home Consuption in South Africa. Master's Thesis, University of Pretoria, Pretoria, South Africa, December 2005.

33. Mathews, C.; Jones, R.B.; Saxena, K.B. Maize and Pigeonpea Intercropping Systems in Mpumalanga, South Africa. Int. Chickpea Pigeonpea Newsl. 2001, 8, 52-53.

34. Fanadzo, M.; Chiduza, C.; Mnkeni, P.N.S.; Van der Stoep, I.; Stevens, J. Crop production management practices as a cause for low water productivity at Zanyokwe Irrigation Scheme. Water SA 2010, 36, 27-36. [CrossRef]

35. Biazin, B.; Sterk, G.; Temesgen, M.; Abdulkedir, A.; Stroosnijder, L. Rainwater harvesting and management in rainfed agricultural systems in sub-Saharan Africa-A review. Phys. Chem. Earth Parts A/B/C 2012, 47-48, 139-151. [CrossRef] 
36. Ebert, A.W. Potential of underutilized traditional vegetables and legume crops to contribute to food and nutritional security, income and more sustainable production. Sustainability 2014, 6, 319-335. [CrossRef]

37. Orsini, F.; Kahane, R.; Nono-Womdim, R.; Gianquinto, G. Urban agriculture in the developing world: A review. Agron. Sustain. Dev. 2013, 33, 695-720. [CrossRef]

38. Rezig, M.; Sahli, A.; Ben Jeddi, F.; Harbaoui, Y. Adopting Intercropping System for Potatoes as Practice on Drought Mitigation under Tunisian Conditions; Instituto Agronómico Mediterráneo de Zaragoza: Zaragoza, Spain, 2010; pp. 329-334.

39. Oelofse, A.; van Averbeke, W. Nutritional Value and Water Use of African Leafy Vegetables for Improved Livelihoods; WRC Project No. K5/1579; WRC: Pretoria, South Africa, 2012.

40. Schönfeldt, H.C.; Pretorius, B. The nutrient content of five traditional South African dark green leafy vegetables-A preliminary study. J. Food Compos. Anal. 2011, 24, 1141-1146. [CrossRef]

41. Kwenin, W.; Wolli, M.; Dzomeku, B. Assessing the nutritional value of some African indigenous green leafy vegetables in Ghana. J. Anim. Plant Sci. 2011, 10, 1300-1305.

42. Faber, M.; Oelofse, A.; Van Jaarsveld, P.; Wenhold, F.; Jansen van Rensburg, W. African leafy vegetables consumed by households in the Limpopo and KwaZulu-Natal provinces in South Africa. S. Afr. J. Clin. Nutr. 2010, 23, 30-38. [CrossRef]

43. Jan van Rensburg, W.; Van Averbeke, W.; Slabbert, R.; Faber, M.; Van Jaarsveld, P.; Van Heerden, I.; Wenhold, F.; Oelofse, A. African leafy vegetables in South Africa. Water SA 2009, 33, 317-326. [CrossRef]

44. Van Jaarsveld, P.; Faber, M.; Van Heerden, I.; Wenhold, F.; Jansen van Rensburg, W.; van Averbeke, W.; Van Rensburg, W.J.; Van Averbeke, W. Nutrient content of eight African leafy vegetables and their potential contribution to dietary reference intakes. J. Food Compos. Anal. 2014, 33, 77-84. [CrossRef]

45. Muzigaba, M.; Puoane, T.; Sanders, D. The Paradox of Undernutrition and Obesity in South Africa: A Contextual Overview of Food Quality, Access and Availability in the New Democracy. In Food Poverty and Insecurity: International Food Inequalities; Caraher, M., Coveney, J., Eds.; Springer: Cham, Switzerland, 2016; pp. 31-41.

46. Leakey, R.R.B.; Nevenimo, T.; Moxon, J.; Pauku, R.; Tate, H.; Page, T.; Cornelius, J. Domestication and Improvement of Tropical Crops for Multi-Functional Farming Systems. Available online: https:/ / researchonline. jcu.edu.au/23329/1/Leakey_2009_4843.pdf (accessed on 30 August 2017).

47. Leakey, R.R.B. Living with the Trees of Life. Towards the Transformation of Tropical Agriculture; Leakey, R., Ed.; CABI: Wallingford, UK, 2012; ISBN 9781780640990.

48. Awodoyin, R.O.; Olubode, O.S.; Ogbu, J.U.; Balogun, R.B.; Nwawuisi, J.U.; Orji, K.O. Indigenous Fruit Trees of Tropical Africa: Status, Opportunity for Development and Biodiversity Management. Agric. Sci. 2015, 6, 31-41.[CrossRef]

49. Kwesiga, F.; Akinnifeshil, F.; Ramadhani, T.; Kadzere, I.; Sakaf, J.; Shumba, E.M.; Lusepani, E.; Hangula, R. Domestication of indigenous fruit trees of the miombo in southern Africa. In Domestication and Commercialization of Indigenous Fruit Trees in the SADC Region; Shumba, E.M., Lusepani, E., Hangula, R., Eds.; SADC Tree Seed Centre Network: Harare, Zimbabwe, 2000.

50. Saka, J.D.K.; Msonthi, J.D. Nutritional value of edible fruits of indigenous wild trees in Malawi. For. Ecol. Manag. 1994, 64, 245-248. [CrossRef]

51. Akinnifesi, F.K.; Kwesiga, F.R.; Mhango, J.; Mkonda, A.; Chilanga, T.; Swai, R. Domesticating priority for miombo indigenous fruit trees as a promising livelihood option for small-holder farmers in southern Africa. Acta Hortic. 2004, 15-30. [CrossRef]

52. Packham, J. The Value of Indigenous Fruit-Bearing Trees in Miombo Woodland Areas of South-Central Africa; Department for Environment, Food and Rural Affairs: London, UK, 1993.

53. Department of Agriculture Forestry and Fisheries (DAFF). Most Common Indigenous Food Crops of South Africa; DAFF: Pretoria, South Africa, 2013.

54. Tran, N.; Bailey, C.; Wilson, N.; Phillips, M. Governance of Global Value Chains in Response to Food Safety and Certification Standards: The Case of Shrimp from Vietnam. World Dev. 2013, 45, 325-336. [CrossRef]

55. Prado, J.R.; Segers, G.; Voelker, T.; Carson, D.; Dobert, R.; Phillips, J.; Cook, K.; Cornejo, C.; Monken, J.; Grapes, L.; et al. Genetically engineered crops: from idea to product. Annu. Rev. Plant Biol. 2014, 65, 769-790. [CrossRef] [PubMed]

56. License, C.A. When gene flow really matters: Gene flow in applied evolutionary biology. Evol. Appl. 2016, 9, 833-836. [CrossRef] 
57. Holme, I.B.; Wendt, T.; Holm, P.B. Intragenesis and cisgenesis as alternatives to transgenic crop development. Plant Biotechnol. J. 2013, 11, 395-407. [CrossRef] [PubMed]

58. Hirakawa, H.; Shirasawa, K.; Miyatake, K.; Nunome, T.; Negoro, S.; Ohyama, A.; Yamaguchi, H.; Sato, S.; Isobe, S.; Tabata, S.; et al. Draft Genome Sequence of Eggplant (Solanum melongena L.): The Representative Solanum Species Indigenous to the Old World. DNA Res. 2014, 21, 649-660. [CrossRef] [PubMed]

59. Dawson, I.K.; Jaenicke, H. Underutilised Plant Species: The Role of Biotechnology. Position Paper No. 1; Crops for the Future: Selangor, Malaysia, 2006; ISBN 9789551560003.

60. Department of Sicence and Technology (DST). The Bio-Economy Strategy; DST: Pretoria, South Africa, 2013.

61. Abdelgadir, H.A.; Kulkarni, M.G.; Arruda, M.P.; Van Staden, J. Enhancing seedling growth of Jatropha curcas-A potential oil seed crop for biodiesel. S. Afr. J. Bot. 2012, 78, 88-95. [CrossRef]

62. Mkandawire, C. Review of bambara groundnut (Vigna subterranea (L.) Verdc.) production in Sub-Sahara Africa. Agric. J. 2007, 2, 464-470.

63. Adoukonou-Sagbadja, H.; Wagner, C.; Dansi, A.; Ahlemeyer, J.; Daïnou, O.; Akpagana, K.; Ordon, F.; Friedt, W. Genetic diversity and population differentiation of traditional fonio millet (Digitaria spp.) landraces from different agro-ecological zones of West Africa. Theor. Appl. Genet. 2007, 115, 917-931. [CrossRef] [PubMed]

64. Vadivel, V.; Janardhanan, K. Nutritional and anti-nutritional attributes of the under-utilized legume, Cassia floribunda Cav. Food Chem. 2001, 73, 209-215. [CrossRef]

65. Mabhaudhi, T.; Modi, A.T.; Beletse, Y.G. Growth, phenological and yield responses of a bambara groundnut (Vigna subterranea L. Verdc) landrace to imposed water stress: II. Rain shelter conditions. Water SA 2013, 39, 191-198. [CrossRef]

66. Chimonyo, V.G.P.; Modi, A.T.; Mabhaudhi, T. Water use and productivity of a sorghum-cowpea-bottle gourd intercrop system. Agric. Water Manag. 2016, 165, 82-96. [CrossRef]

67. Van Averbeke, W. Indigenous Technology and Technology-Oriented Research: Implications for Research Methodology. In Proceedings of the 18th Annual Conference of the Association for International Agricultural and Extension Education, Durban, South Africa, 26-30 May 2002; pp. 451-457.

68. TerAvest, D.; Carpenter-Boggs, L.; Thierfelder, C.; Reganold, J.P. Crop production and soil water management in conservation agriculture, no-till, and conventional tillage systems in Malawi. Agric. Ecosyst. Environ. 2015, 212. [CrossRef]

69. Kennedy, G.L.; Pedro, M.R.; Seghieri, C.; Nantel, G.; Brouwer, I. Dietary diversity score is a useful indicator of micronutrient intake in non-breast-feeding Filipino children. J. Nutr. 2007, 137, 472-477. [PubMed]

70. Edelman, M.; Weis, T.; Baviskar, A.; Borras, S.M.; Holt-Giménez, E.; Kandiyoti, D.; Wolford, W. Introduction: Critical perspectives on food sovereignty. J. Peasant Stud. 2014, 41, 911-931. [CrossRef]

71. Uusiku, N.P.; Oelofse, A.; Duodu, K.G.; Bester, M.J.; Faber, M. Nutritional value of leafy vegetables of sub-Saharan Africa and their potential contribution to human health: A review. J. Food Compos. Anal. 2010, 23, 499-509. [CrossRef]

72. Fasoyiro, S.; Ajibade, S.; Omole, A.; Adeniyan, O.N.; Farinde, E.O. Proximate, minerals and antinutritional factors of some underutilized grain legumes in south-western Nigeria. Nutr. Food Sci. 2006, 36, 18-23. [CrossRef]

73. Wang, M.; Fu, Y.; Liu, H. Nutritional status and ion uptake response of Gynura bicolor DC. between Porous-tube and traditional hydroponic growth systems. Acta Astronaut. 2015, 113, 13-21. [CrossRef]

74. Singels, A.; Annandale, J.G.; De Jager, J.M.; Schulze, R.E.; Steyn, J.M. Modelling crop growth and crop water relations in South Africa: Past achievements and lessons for the future. S. Afr. J. Crop Sci. 2010, 37-41. [CrossRef]

75. Department of Agriculture Forestry and Fisheries (DAFF). National Policy on Food and Nutrition Security. Available online: http:/ / www.daff.gov.za/docs/media/NATIONALPOLICYonfoodandnutriritionsecurity. pdf (accessed on 30 August 2017).

76. Wheeler, T.; von Braun, J. Climate change impacts on global food security. Science 2013, 341, 508-513. [CrossRef] [PubMed]

77. Shindell, D.; Kuylenstierna, J.C.I.; Vignati, E.; van Dingenen, R.; Amann, M.; Klimont, Z.; Anenberg, S.C.; Muller, N.; Janssens-Maenhout, G.; Raes, F.; et al. Simultaneously mitigating near-term climate change and improving human health and food security. Science 2012, 335, 183-189. [CrossRef] [PubMed] 
78. Cooper, P. J. M.; Dimes, J.; Rao, K. P. C.; Shapiro, B.; Shiferaw, B.; Twomlow, S. Coping better with current climatic variability in the rain-fed farming systems of sub-Saharan Africa: An essential first step in adapting to future climate change? Agric. Ecosyst. Environ. 2008, 126, 24-35. [CrossRef]

79. Rosegrant, M.; Koo, J.; Cenacchi, N.; Ringler, C.; Robertson, R.; Fisher, M.; Cox, C.; Garrett, K.; Perez, N.; Sabbagh, P. Food Security in a World of Natural Resource Scarcity: The Role of Agricultural Technologies; IFPRI: Washington, DC, USA, 2014.

80. Wehmeyer, A.S. The nutrient composition of some edible wild fruits found in the Transvaal. S. Afr. Med. J. 1966, 40, 1102-1104. [PubMed]

(C) 2017 by the authors. Licensee MDPI, Basel, Switzerland. This article is an open access article distributed under the terms and conditions of the Creative Commons Attribution (CC BY) license (http://creativecommons.org/licenses/by/4.0/). 